\title{
MEMORIALIZING A LEGENDARY FIGURE: BAYAJIDDA THE PRINCE OF BAGDAD IN HAUSA LAND
}

\author{
Abubakar Aliyu Liman \\ Ahmadu Bello University Zaria, Nigeria
}

\begin{abstract}
This paper examines the various ways in which the Bayajidda legend is memorialized. In its current manifestations, the legend can be seen as an important agency for the remembrance of the past in the context of rapid socio-historical change in Africa, under the influence of modernity, technology and globalization. The analysis begins by highlighting the interface between folklore and history in everyday cultural practices in postcolonial northern Nigeria. The signposts that give a coherent structure to the paper include the chronicles of the Bayajidda legend, the essential oral version circulating in its different forms in Hausa society. Over the years, reference to the legend of Bayajidda has always been made through the use of different modes of cultural expression such as song, dramatic performance, film and other forms of narration. This range has served the political and ideological interests of the dominant power elite who are consistently alluding to the Bayajidda legend. The survival of the essential oral narrative therefore depends solely on a strategy of alluding to the legend in its various guises, including the form of museum artifacts, drama, films and musical songs. However, the paper explores each of the specific historical periods from the pre-colonial down to the colonial and postcolonial epochs with a view to highlighting how specific forms of the legend are deployed by hegemonic structures for the purposes of legitimation.
\end{abstract}

KEYWORDS: BAYAJIDDA, LEGEND, HISTORY, HAUSA KINGDOM, MEMORIALIZATION, RECREATION

\section{Introduction}

The analysis below is divided into three broad categories. To wit, History and Folklore, Bayajidda Legend, and Memory and Representation. The first deals with the interpenetration of history and folklore in the production of memory and remembrance of the Bayajidda legend. The second section elucidates on the Bayajidda legend as the foundational narrative in the evolution of ancient Hausa kingdoms. The third section explores the various media through which the Bayajidda legend is memorialized.

\section{History and Folklore}

In Hausa cultural formation, different modes of cultural signifying practices such as performing arts and oral narratives have variously drawn their ingredients from the Bayajidda legend. In a number of instances, the performing artists have ideologically turned the Bayajidda legend into a veritable frame of reference of the essence and existence of Hausa 
people (Liman 2008: 16; Liman 2010: 99). Ironically, this same story of a legend is also used to trace the genealogy of the so-called Fulani aristocracy, which ended the ancient Habe dynasty established by the descendants of Bayajidda (Kuper and Smith 1969: 135). The legend is also deployed for different reconstructions of Hausa being and identity in northern Nigeria. The Hausa world has passed through different historical epochs that have seen varying socio-cultural transformations over the eons. With hindsight, it now appears that every historical period in the society has alluded to or appropriated the Bayajidda legend for various political and ideological reasons. It has become very clear that the narrative of the legendary Hausa figure was indeed deployed to serve complex socio-political agendas and cultural dynamics (Palmer 1967). In the process, the collective identity of the Hausa people is consistently renegotiated or reconstructed. Disciplinary enclaves as diverse as history, literature, anthropology and museology have in one way or another highlighted the Bayajidda legend in their own modes of discourse.

Similarly, in its varying cultural shades, the Bayajidda legend has played a significant socio-political role in the processes of state formation and indeed in the overall evolution of Hausa culture and society (Smith A. 1987: 104). This can be glimpsed through its manifestations in different historical phases from the earlier period of state formation during the emergence of Habe dynasty (non-Fulani Hausa rulers) to the establishment of the Sokoto Caliphate, the historical moment in which a centralized Pan-Islamic Emirate system was formed (Smith 1987: 59). The legend has indeed continued to serve other cultural purposes during the period of Indirect Rule under British colonialism, and in the current postcolonial age and globalization processes where the logic of the nation state seems on the decline.

Furthermore, two important perspectives on memory and remembrance can be found in the way both folklore, history and even anthropology are deployed in this important narrative for the purposes of legitimation or de-legitimation, as well as by using the legend turning it into an instrument of identity construction in the context of colonial and postcolonial geopolitical contestations in northern Nigeria (Kuna 2005: 413). While folklore appropriates subjective resources to validate its claims, history insists on an objective, factual and empirical rendition of its object of analysis (Smith 1987: 55). Thus, in the contemporary Hausa cultural landscape the various ways in which the Bayajidda legend is remembered has demonstrated that the boundary between folklore and history is almost completely blurred. In a way, this has validated the thesis advanced by Jan Vanisina who holds that aspects of oral tradition are continuously remembered or memorialized in the cultural framings of society (Vanisina 1985: 147). In any case, the intertwining of folklore and history is more cogent when the narrative of any legendary figure is treated as allegory in order to produce its possible meaning or historicity as exemplified by the movement of the Bayajidda legend in history (Lange 2012: 138).

\section{The Bayajidda Legend}

The narrative of the Bayajidda legend in Hausa folklore indicates that the origin of the Hausa kingdoms is always associated with story of a prince of Baghadad, Abu Yazid or Baayajjdda, who migrated from his distant homeland in the Middle East to Hausa land in 
northern Nigeria. Bayajidda's journey took him westwards as he crisscrossed different empires and cultures to reach Hausa land in West Africa where he pioneered the genealogies of Habe dynasty of the ancient Hausa kingdoms. Again as the legend would have it, when Bayajidda arrived on Hausaland he was said to have taken a female queen, the matriarch of Daura. In historical accounts, Daura is believed to be the spiritual home of the ancient Hausa kingdoms. Daurama (clearly driven from the word Daura) is the name of the queen who at that material time was the sovereign monarch of Daura, one of the leading Hausa city-states, if not the most important ancient spiritual hub of the Hausa people.

According to the folkloric version of the Bayajidda story, Daurama became the queen of the most important centers of Hausa civilization while still as an unmarried princess. She remained unmarried until the arrival of the brave and charming prince all the way from Baghdad in Arabia. Queen Daurama was persuaded to marry Bayajidda basically on account of his bravery and good looks. How did this happen? At the point of his entry into the city of Daura, on the outskirts of the city Bayajidda knocked at the door of an old woman named Ayana who, in the spirit of traditional Hausa hospitality, accepted to host him and his entourage as guests in her home.

Bayajidda was thirsty and exhausted, so asked the old woman for water to quench his thirst, and to do the same for his entourage who were also fatigued after their long journey from Borno. Borno kingdom is where he first settled down and even married princess Magira the daughter of the King of Borno. Bayajidda has to depart Borno unceremoniously. He is compelled to leave when he was caught up in the web of palace intrigues and treachery hatched up by a coterie of envious princes and courtiers of the Borno kingdom. The envy of Bayajidda's detractors began to manifest itself when they noticed that he was winning the confidence of the sovereign monarch of Borno. His intelligence, wisdom, martial skills and bravery were the qualities that attracted him to the King of Borno. As the plot against Byajidda thickened, his princely opponents alleged that Bayajidda was plotting to unseat his father in-law from the enviable throne of the great kingdom of Borno. The Mai (King) of Borno was ultimately persuaded by the gossiping detractors that Bayajidda was plotting to dethrone him. He then ordered the immediate arrest and execution of Bayajidda. Fortunately the King's directive was leaked to Bayajidda via his wife Magira, the daughter of the Mai. Her servants had informed her of the plots of rival princes to get rid of Bayajidda. On hearing of his arrest warrant, he hastily packed his belongings, and along with his wife and lieutenants, and left the kingdom quietly under the cover of the night before the palace guards could arrest him.

At the point Bayajidda was forced to leave Borno, princess Magira was heavily pregnant with their first child. As a result, he could not have possibly travelled very far with her. He then decided to stop over at Garun Gabas (Biram), a town located in the heartland of Hausa country. Garun Gabas is a place that is safely located far from the territories under the control of the king of Borno. He decided to leave his wife behind at Garun Gabas by placing her in the custody of the patriarch of the town, who together with members of his household expressed their sympathy over the plight of Bayajidda and his entourage. They also accepted to host his expecting wife. He promised to return for her after safe delivery of her baby. 
After settling his wife at Garun Gabas, Bayajidda continued on his journey west into the central regions of Hausa land. He finally arrived at a place called Daura where once again he married - this time the sovereign queen of Daura herself. Bayajidda's marriage to queen Daurama was preceded by dramatic events in which he demonstrated his courage by killing the mysterious serpent known as Sarki. The sepernt had prevented people from fetching water from Kasugu, the only well in town, except on Friday. Bayajida defied the danger posed by the serpent by taking the risk of going to the well to fetch water in order to quench his thirst, and that of his exhausted entourage and horses. Bayajidda visited the well from his abode in the old woman's home on a Thursday night. When the snake called Sarki (Hausa word for king) attempted to prevent him from drawing water from the only well in the town, Bayajidda took his sword and cut off the head of the snake as it attempted to strike him from inside the well. The news of Bayajidda's deed immediately reached queen Daurama. There and then, she promised to cede half of her kingdom to the person who removed the mysterious snake that prevented people from fetching water from the well throughout the days of the week. Many pretenders claimed that they had beheaded the serpent, but were exposed as they were unable to produce concrete evidence that they had actually killed the serpent.

On hearing of this development, the old woman Ayana visited the queen to report that she suspected it was her guest that had killed the serpent. She told queen Daurama that the stranger who came to her house the previous day is the fellow that has killed the serpent. She recounted how she attempted to dissuade him from going to fetch water on that odd day, but he insisted on going. He went out to the well in the dark of the night and came back with water for his people and horses. Queen Daurama promptly summoned Bayajidda and cross-examined him. He produced before her the mammoth head of the mysterious serpent. The head of the snake was reported to resemble the head of a horse in size. Bayajidda however refused to accept the gift of one half of the kingdom promised by the queen. He instead asked for her hand in marriage, which she gladly offered.

Before long queen Daurama became ill at ease and apprehensive over her inability to bear children for Bayajidda. She feared that she would not be able to bear children because she had been single for such a long period in her own kingdom. To fulfill the desire of having a child for Bayajidda, she promptly decided to give a slave woman to Bayajidda to serve as his concubine for the sole purpose of bearing children. The slave woman immediately became pregnant and eventually delivered a baby boy to Bayajidda. The baby boy was named Kamagari (town-seizer). Not long afterwards, queen Daurama herself also became pregnant. She gave birth to another male child for Bayajidda. Her own child was named Bawogari. Her marriage to Bayajidda was after all very fruitful because a potential heir apparent to the throne of Daura had emerged from their union. Eventually, the two sons of Bayajidda from the queen and the concubine grew to become men. They in turn married two different women. Consequently, each one of the wives was blessed with several male children.

The six children of Bawogari all happened to grow on the diet of their grandfather's bravery and warrior spirit. This prepared them to set out in search of their own adventu- 
res. In the process, they founded settlements that became the Hausa Kingdoms of Gobir, Kano, Rano, Zazzau, Katsina and Biram, together with Daura that was earlier ceded to their father by Queen Daurama. The kingdoms founded by the sons of Bawo were considered as the seven legitimate kingdoms (Hausa Bakwai) by virtue of their direct descent from Queen Daurama. However, in some other historical accounts, the seventh son who became the sovereign king of Biram happened to be the direct grandchild of the Borno princess whom Bayajidda had earlier married in Borno before his arrival at Daura in Hausa land. Evidently, the line from Borno aristocratic woman was the genesis of Habe dynasty in Hausa kingdoms, particularly through her lineage. This foundational narrative has become an important subject of mimetic representations over the centuries (Smith 1987; Palmer 1967; Anonymous 2007; Lange 2012).

History has recorded that Habe rulers ruled Hausa kingdoms for more than five centuries before the dethronement of the dynasty in the $19^{\text {th }}$ century by the forces of Sokoto Jihad who eventually established a Caliphate led by Sheikh Usman bin Fodio (Hiskett 1984: 165). The other component of the Bayajidda narrative is the one concerning his concubine from Gwari ethnic extraction who gave birth to his other child named Kamagari. Kamagari's children in turn were also said to have proceeded to found another set of seven Hausa kingdoms albeit regarded as illegitimate Hausa states (Banza Bakwai). The illegitimate Hausa kingdoms included Kebbi, Zamfara, Gwari (Birnin Grawi), Kwararafa (Jukun), Oyo (Yoruba), Nupe and Yauri. Even though the sons of Kamagari (Bayajidda's son sired by a concubine) were from the royal bloodline, the kingdoms they had founded were considered illegitimate because their father was the son of an illegitimate wife (Smith M.G 1964: 340)

\section{Memory and Representation}

The narrative on the Bayajidda legend above is abstracted from its various renditions ranging from oral sources, musical songs (Gusau 2009: 29), museum artifacts (Lawan 2015; 2018) and films (Jibrin 2015). Although the narrative of a legendary Hausa figure is deeply entrenched in the folklore of the Hausa people, its retention in the memory of individuals and in different chronicles regarding the origin of ancient Hausa states has occurred for different ideological purposes. However, subsequent analysis will show that the narrative has meant different things to different people in different historical periods, with the evolution of Hausa society from the ancient period to the present.

The need for cultural preservation through the reenactment of the Bayajidda legend is necessary for the reconstruction and revalidation of what has come to be known as common Hausa identity within the socio-political dynamics of postcolonial Nigeria. This is achieved through the reintroduction of pristine identities of pre-colonial Nigerian communities using available media. Historians of the Central Sudan such as Abdullahi Smith have questioned the rationale and authenticity of the Bayajidda narrative in historical reconstructions (Smith 1987: 104), but somehow they concur that the legend has at least served as an important means of legitimation and identity construction in the cause of state formation. (Liman 2004: 17). 
Historians, colonial historians most especially, have variously analyzed the Bayajidda legend. H.R. Palmer in the Sudanese Memoirs, a collection of Arabic manuscripts, local chronicles, Arab and European travelogues, has made a detailed translation of the histories of the people occupying the territories of Central and Western Sudan. The British colonial accounts of the entire history of Daura seem to have been sourced from documents that were largely written in Arabic. On the specific issue of Bayajidda, Palmer relied on a written document called the Girgam. The Girgam chronicle was believed to be an orally based document, which is largely "re-written from memory" (Palmer 1967: 132, Hodgkin 1975: 74). M.G. Smith (1966) has confirmed the written sources of the Bayajidda story. He collected two written narratives that recounted the Bayajidda episode from the leading Islamic clergy of Daura, Limamin Daura Malam Ishaka.

The document recorded how Abu Yazidu (as Hausa folk singers called Bayajidda), the son of Abdullahi, the king of Baghdad, had a misunderstanding with his father and the people of his hometown. As a result he left home and embarked on a journey to Black Africa. In M.G. Smith (1966), Queen Daurama's origin was traced to the East. Dierek Lange has even described her as "the Canaanite queen of Daura" (Lange 2012: 138). She is said to be the youngest daughter of one Abdul Dar, the son of Najib the Canaanite. Najib set out from Canaan to settle in Libya. Later his son Abdul Dar moved southwards across the Sahara to a place called Kusugu in Hausaland. Kusugu is of course the name of the well in Daura where a notorious serpent prevented people from drawing water on some designated days. The title adopted by matrilineal rulers of Daura is Magajiya. There were in fact about 17 Magajiyas (queens) in Daura before the establishment of a completely patrilineal Habe dynasty with the rule established by the descendants of Bayajidda. The establishment of mega Hausa states under male leadership has apparently signaled the beginning of patriarchy in Hausaland; a conscious and deliberate perpetuation of patriarchal values and ideology; and, a gradual gravitation towards the idea of nationhood on account of shared values and culture among the Hausa speaking people. From this history, tracing the origin of the Hausa people to the East has merely reaffirmed the rootedness and significance of Islam to Hausa culture and society at the crucial moment of state formation before the period of British colonialism.

However, interest in the Bayajidda legend among colonial historiographers reflects the efforts made by the colonial establishment to unravel the processes of state formation in the pre-dynastic and dynastic periods in the evolution of Hausaland. This can still be seen in Palmer's interpretation of the Bayajidda narrative as something that inaugurated more complex socio-political, economic and cultural transformations in Hausaland. There is of course the emergence of a new form of worship in a society that was until then deeply enmeshed in animist practices; a prelude to the patrilineal system of rule and succession; the introduction of donkeys, mules and horses in Hausa society; and, the new construction technology (Palmer 136). Hogben and Kirk-Greene have corroborated Palmer's assessment.

The Daura legend may be considered as celebrating four important new ways of life introduced by foreign immigrants. First, there was the introduction into Hausaland 
of a new form of worship by the killing of the fetish snake. Then there was the introduction of the donkey, and the art of well-digging through rock to save the dangerous night journeys to the river. Finally, there was the replacement of the traditional Sudanic custom of matrilineal descent by the patrilineal system of the Berbers and Arabs (1966: 147).

The Bayajidda legend is indeed treated as an allegory that symbolizes tectonic historical developments with the increasing rates of migration of people from the Middle East and North Africa into West African hinterlands. It has revealed that the introduction of Islam in Hausaland that accompanied the migrations brought with it extensive cultural changes in society which lasted until the establishment of the Sokoto Caliphate and the adoption of Islam as the ruling ideology in the $19^{\text {th }}$ century (Usman 1979: 34).

But how has the Bayajidda legend faired in the transition period between colonial rule and self-rule in Northern Nigeria? Here, the folkloric element has superseded historiography as the representational means of recounting the Bayajidda saga. Under the system of Indirect Rule introduced in the region by the British, the scions of the Emirate system had enjoyed considerable powers and leverage on the basis of the system of Native Authority (Yahaya 1980). This was an arrangement in which colonial subjects were effectively controlled through a cloned leadership that was put in place even before the British colonial conquest of the territories of the Sokoto Caliphate. However, although the Indirect Rule structures and hierarchies of power were retained, the British had encouraged the disruption of the Emirate political structures by attempting to privilege some Emirs over others, particularly those considered as friends of the British Empire. This type of relationship created a new climate in which, despite the political hierarchy of Northern Nigerian House of Chiefs (an equivalence of House of Lords in England), other Emirs began to take independent initiatives by getting closer to colonial officials while at the same time distancing themselves from the authority of Sultan of Sokoto, the spiritual Head of the Emirate system in Northern Nigeria that operated as loose federations, and as relatively autonomous political entities (Yahaya 2005: 238).

Nowhere is this political reality better articulated than in the songs of Hausa court singers. The colonial phase of Northern Nigerian history has characteristically distinguished itself as the golden age of the feudal culture, expressed and celebrated through such high art forms as court praise-singing, colorful equestrian culture of Durbar and Sallah festivals. Individual Emirates staged these performances on different festive occasions. They periodically staged these performances purposely to entertain their European guests. The Emirs also organized flamboyant performances at the Kaduna seat of the Northern Nigerian regional government, especially during annual meetings. The Emirs engaged the court praise singers on the basis of a patron-client relationship in an era in which famous performing artists produced their panegyrics exclusively for the aristocratic class. Court singers who were completely tied to their aristocratic patrons composed songs for those patrons and other members of the aristocracy considered friends of the singers' patrons. In their songs, as they praise the friends of their royal patrons they also lampoon the opponents 
of their benefactors through innuendo, banter, punning and scathing criticism. Reality is completely viewed from the prisms and interests of their patrons (Liman 2004: 21).

The praise singers composed and performed their songs specifically in the context of the political dynamics of the age, during the period of transition to political independence and self-rule. The court singers usually highlight two significant dimensions. Firstly, they have in their songs tended to subordinate the dominant political arrangements instituted into British colonialism under the power and influence of the Native Authority, the Emirate political system that was integrated to British colonial administration. Secondly, they disrupted and deconstructed the Emirate leadership values through the invocation of pre-Jihad Habe power structure and ideology. For instance, whenever the Daura Emirate, which used to serve as the spiritual home of ancient Hausa culture and civilization during Habe dynastic rule, or even when the Emir of Daura is projected in Hausa court songs, the motif of the Bayajidda legend is usually invoked as an oppositional narrative, to negate the political control of the predominant Fulani hegemony of the Sokoto Caliphate and the creeping realities of colonial modernity (Kukah 1994: 5).

For example, Aliyu Dandawo is a praise-singer tied to the Emir of Kabin Argungu, a Habe entity notorious for its strong resistance against the $19^{\text {th }}$ century Sokoto Jihad in Hausaland. Dandawo is noted for his provocative celebration of the stiff resistance put up by Habe rulers of Kabi to the Jihad waged by Sheikh Usman bin Fodio against them. In one of his songs on the working tour of Emir of Kabin Argungu to other provinces of Northern Nigeria, which is part of his Native Authority schedules, titled "Sarkin Kabi Muhammadu", the singer recounted the places his Emir patron visited in different provinces, divisions and districts of Northern Nigeria including Sokoto, Gusau, Funtua, Zaria, Kaduna, Katsina and Daura, respectively. On arrival at Daura, Dandawo lyricized how the Emir of Daura pleasantly extended his traditional hospitality to the visiting Emir. The singer recited how his patron visited important historical sites and the museum (Gidan Tarihi) where memorabilia such as the sword used by the legendary Bayajidda to slay the serpent at the Kasugu well, ancient regalia and war drums were all kept. He also visited the famous Kusugu well where the episode of slaying of the serpent took place. Old lady Ayana, Bawogari the son of Bayajidda and the mysterious snake were all mentioned in the song:

Lead Singer:

Ya ga rijiyan nan da aka hwadi/

Wadda ac cikin tarihi

Yaji wada Bawa yay yi da Ayana

Chorus:

Ya shiga cikinta ya kasha macijiya

Translation.

Lead Singer:

He saw the well that was mentioned

There in history 
He heard what Bawa told Ayana

Chorus:

He entered the well and killed the snake (Gusau 2009: 29).

Moreover, Dandawo's oral rendition has not failed to recognize the fact that the Bayaidda narrative has been well preserved through those museum artifacts, other memorabilia as well as written documents (Anonymous 2007: 39).

In another narrative song, Ibrahim Danmaraya made a panoramic rendition of the Bayajidda episode in a style that can simply be defined as a monologue in which the entire history of the Hausa legend is expressed in the manner typical of African lyrical performances. From the version of this performer, Bayajida's journey on horse back, or in some other tales on a mule, started from Baghdad, detoured for a while in Egypt before proceeding to his final destination at Daura in the Central Sudan. However, from my readings there appear to be some mix-ups in Danmaraya's version, especially when he claimed that Bayajidda, Abu Yazidu in his lyrics, was in Egypt and was embroiled in an issue concerning the unique horse of the King of Egypt. As far as this version goes, Bayajidda found a way of using the semen of the King's horse to impregnate his mare. The result was a crossbreed that was identical to the King of Egypt's horse. The King of Egypt discovered the infraction. He became very angry and ordered the execution of Abu Yazidu. But Abu Yazidu mounted his hybrid and ran for his dear life westwards until he reached Daura in Hausa country (Gusau 2005: 203). This version of the Bayajidda legend projected by the performer is not entirely new. Lots of other oral versions have shared the same motifs and plot structure. Perhaps this can be seen as a clear case of verbal variability that is typical of all oral art forms.

In contemporary Nigeria, cultural symbols and artifacts have become the most important means of identity construction, judging by the way in which they nourished micro nationalism and politics of legitimation in the context of geopolitical agitations of plural identities (Liman 2004: 20). Identity formation manifests itself more clearly in the realm of cultural symbolism. That is to say, competing ethnic configurations and individuals in different parts of the country tend to express themselves through identity markers, "a picture of a Nigerian cultural identity that can be likened to a variegated map with different motifs and of different hues - some modified patterns, some new impositions in striking colours and some unchanging survivals" (Awe 1989: 9). Often, this form of ethnic nationalism and self-reassertion are done through the flamboyant showcasing of cultural symbols, artifacts, specific colors and cloth designs. To this end, any keen observer can easily recognize the identity of every Nigerian from the style, color and design associated with the group to which she or he belongs. In Nigeria, it is difficult to define national culture or values outside ethnic loyalties and associations because the evolving civic culture is competing for space with primordial modes of cultural expression (Ekeh 1989: 12). Every ethnic group is more at home with its own cultural constructs and means of group self-identification. Each major or minor ethnic group is consciously and uniquely reasserting its own definition of identity in its own peculiar way and manner. This is to the extent 
that ethnic identity has more or less become the determining factor of politics of cultural expression. It is also the sense in which cultural representation is more inclined towards the promotion of specific ethnic histories. For instance, the desire to sustain the myth of the evolution of Hausa people from stateless entities to more centralized kingdoms, the ancient city of Daura has established a museum (gidan tarihi) to preserve the memory of Bayajidda where the well from which the serpent prevented people from fetching water, the sword and the armor of Bayajidda were all housed.

As a foundational narrative, the Bayajidda legend has also become the stuff of dramatic renditions in different towns and cities of Northern Nigeria. Drama groups known as Damaga in the Hausa language have been responsible for the reenactment of the story of Bayajidda in social clubs where individuals pay gate fees to gain access to the club theatre. In Funtua, a town in Katsina state of Nigeria, there is even a drama club that is called Bayajidda Drama Club. One of the most popular shows they stage is the Bayajidda's journey to Hausa land; his encounter with the serpent at the only well in the old city of Daura; his marriage to queen Daurama; and, the birth of his progenitors that established the Habe dynasty in the ancient Hausa kingdoms. Dramatic renditions of the Bayajidda legend are some of the most important means of sustaining memory and remembrance (Liman 2008: 155). However, the influence of puritanical Islam from the mid 1980s is threatening to destroy traditional drama and the performing arts in Hausa society.

Again, in the digital enclaves of our postcolonial world traditional means of cultural signifying practices and performances are fast giving way to newer modes of representation that are everywhere determined by electronic media technology. As is clearly evident, the euphoria to digitize African oral performances is saturating our entire cultural space. Kannywood video film rendition of the Bayajidda legend is couched in the logic of this form of mediated reality. One interesting aspect of the visual version is the way in which it stylistically appropriates flashback technique, story within story devices, and a traditional system of the position of a narrator in narration. The storyline in the film has squarely conformed to the commonplace version that is cited above at the beginning of this analysis. But, what is the purpose of producing the video version of this narrative? Why are the producers of the video film dipping into the Hausa folkloric repertoire to bring out this ancient narrative of Hausa legendary figure at this point in history? Is this effort simply meant as entertainment or for something else? At this juncture, it is argued that the opening up of African traditional cultures through digital media representations is nothing but a process of "de-territorialization" and appropriation of all indigenous and local cultures by the raging processes of cultural globalization. That is to say in the postmodern age cultural globalization has tended to accentuate a paradigmatic shift from previous systems of cultural signification to the present context of visual and digital representations (Storey 2003: 107; Baker 2013: 369). 


\section{Conclusion}

From the preceding analysis, African oral performances have consistently proven to be the important repertoire through which the history of the people is nurtured and sustained. There is yet another way in which oral traditions have helped to sustain memory and remembrance. Each generation of Hausa people appropriates oral forms and utilizes them differently on the basis of available media technology. In this regard, the Bayajidda legend has undergone a lot of transformation from its purely oral narrative version to written version, lyrical version, museum version and cinematic version. Each of these versions has indeed played some crucial role in the socio-political development of Hausa society, and in identity politics and geopolitical contestations in contemporary Nigeria. The interface of folklore and history in the postmodern context and the processes of cultural globalization through ubiquitous electronic media, for instance, have accentuated the way in which digitized forms of oral performances are deepening memory and remembrance of Africa's cultural and historical past and present.

\section{References}

Anonymous, (2007). A Brief History of Daura, Produced Specially for the Coronation of the 60th Emir of Daura Alhaji Umar Faruk Umar, CON, Daura: Amana Press

Awe, B. (1989). "Nation-building and Cultural Identity: The Colonial Experience", in Nigeria Since Independence: The First 25 Years, Volume VIII Culture, ed. Ekeh P.P. and Ashiwaju G., Ibadan: Heinemann Publication

Baker, C. (2013). Cultural Studies: Theory and Practice, London: Sage

Ekeh P.P. (1989). "The Scope of Culture in Nigeria”, in Nigeria Since Independence: The First 25 Years, Volume VIII Culture, ed. Ekeh P.P. and Ashiwaju G., Ibadan: Heinemann Publication

Gusau, S.M. (2009). Diwanin Wakokin Baka: Zababbun Matanoni na Wakokin Baka na Hausa, Kano: Century Research and Publication, Pp. 29

- (2005). Makada da Mawakan Hausa, Kano: Benchmark Publication

Hodgkin, T. (1975). Nigerian Perspectives: An Historical Anthology, London: Collins Publication.

Hogben, S.J. and Kairk-Greene, A.H.M. (1966). The Emirates of Northern Nigeria: A Preliminary Survey of their Historical Traditions, Oxford: Oxford University Press

Kukakah, M.H. (1994). Religion, Politics and Power in Northern Nigeria, Ibadan: Spectrum Books Publication

Kuna, M.J. (2005). "Coloniality and the Geography of Conflicts: A Typology" in Yakubu, A.M. et al. Northern Nigeria: A Century of Transformation, 1903 - 2003, Kaduna: Baraka Press

Kuper,L. and M. G. Smith (1969). Pluralism in African Societies, Berkeley: University of California Press.

Lange, Dierek. (2012). "The Bayajidda Legend and Hausa History" in African Zion: Studies in Black Judaism, ed. Edith Bruder and Tudor Parfitt, Newcastle: Cambridge Scholars Publication, Pp. 138

Lawan, M.S. (2018). Zuwan Bayajidda Daura: Shiri na Biyu, YouTube NTA News documentary presented by National Television Authority (NTA), Daura, Katsina State, Nigeria, April I.

- (2015). Legendary Kusugu Well and Artifacts in Daura, YouTube NTA News documentary, by National Television Authority (NTA), Daura, Katsina State, Nigeria, June 13.

Liman, A. A. (2004) "Identity Formation, Post Identity Space and Cultural Canons: The Case of Hausa Court Songs", a book chapter in Voices and Visions from Nigeria: Selected Essays on Art and Culture (ed.) Ikwuemesi C., and Nwafor O. Enugu: African Press 
- (2008) "Hegemony and Mass-mediated Culture: A Study of Popular Culture Trends in Postcolonial Northern Nigeria", Unpublished PhD submitted to Department of English and Literary Studies, Faculty of Arts, Ahmadu Bello University Zaria, Nigeria

- (2010). "Literature, Identity and Civilization: The Challenge of Ignorance in Hausa Cultural Formation", in ISALA, Ife Studies in African Literature and the Arts, Department of English, Obafemi Awolowo University, Ile Ife, Nigeria

Lyotard, J. (1997). The Postmodern Condition: A Report on Knowledge, Manchester: Manchester University Press

Palmer, H.R. (1967). Sudanese Memoirs, Lagos: Macmillan Press.

Smith, A. (1987). A Little New Light: Selected Historical Writings of Abdullahi Smith, Zaria: Gaskiya Corportion Publication

Smith, M.G. (1964). "The Beginnings of Hausa Society, AD 1000-1500" in The Historian in Tropical Africa: Studies Presented and Discussed at the Fourth International African Seminar at the University of Dakar Senegal 1961, ed. J. Vansina, R. Mauny and L.V.Thomas, London: Oxford University Press, Pp. 340

Smith, M.G. (1966). Government in Zazzau, London: SOAS Publication.

Storey, J. (2003). Inventing Popular Culture, Malden: Blackwell

Usman, Y.B. (1979). "The Transformation of Political Com

Vansina, J. (1985). Oral Tradition as History, Madison: The University of Wisconsin Press

Yahaya, A.D. (1980). The Native Authority System in Northern Nigeria, 1950-1970. A Study in Political Relations with Particular Reference to the Zaria Native Authority, Zaria: ABU Press

- (2005). Traditional Leadership and Institutions: The Colonial Transformation of the Emirates", in Northern Nigeria: A Century of Transformation, 1903-2003, ed. A.M. Yakubu, L.M. jUMARE and A.G. Saeed, Kaduna: Baraka Publication 